\title{
Health care utilization and survival among patients with AIDS in Belo Horizonte, Minas Gerais, Brazil
}

\author{
Utilização de cuidados de saúde e sobrevida \\ entre pacientes com AIDS em Belo Horizonte, \\ $M$ inas Gerais, Brasil
}

Francisco de Assis Acurcio 1

Cibele Comini Cesar 2

Mark Drew Crosland Guimarães 3

\footnotetext{
1 Departamento de Farmácia Social e Curso de Doutorado em Ciência Animal, Universidade Federal de Minas Gerais. Av. Olegário Maciel 2360, Belo Horizonte, MG 30180-112, Brasil. 2 Departamento de Estatística, Universidade Federal de Minas Gerais. Av. Antonio Carlos 6627, Belo Horizonte, MG 31270-901, Brasil. 3 Departamento de Medicina Preventiva e Social, Universidade Federal de Minas Gerais. Av. Alfredo Balena 190 10 o andar, Bel o Horizonte, MG, 30130-100, Brasil.
}

Abstract A historical cohort study was conducted in three public AIDS referral services in Belo Horizonte, Minas Gerais, to assess the relationship between health care utilization and patient survival following AIDS diagnosis. A review of medical and laboratory records was performed for HIV-infected patients seeking care for the first time in 1989-92. Among 291 patients initially categorized as "A" [asymptomatic, acute HIV, or persistent generalized lymphadenopathy-PGL] or "B" [symptomatic, non-"A", or AIDS-indicator conditions] (CDC, 1992) and who progressed to AIDS, 57.0\% died. Mortality rate was 34.9/1.000 person-months. Overall median survival time foll owing AIDS diagnosis was 14.3 months. Multivariate analysis showed that lack of AZT use $(\mathrm{RR}=1.87 ; 95 \% \mathrm{Cl}=1.34-2.61)$, advanced initial staging $(\mathrm{RR}=1.68 ; 95 \% \mathrm{Cl}=1.20-2.35)$, 9 or more in patient days ( $R R=1.55 ; 95 \% \mathrm{Cl}=1.11-2.17$ ), and intervals between outpatient visits longer than 6 months ( $R R=0.30 ; 95 \% \mathrm{Cl}=0.16-0.56$ ) were associated with death. The analysis suggests that: Patients who used health services more often had poorer prognosis; Patients who received AZT survived Ionger than those who did not; and Variables u sed to assess health care utilization actually express the end of a process involving seeking and obtaining care.

Key words AIDS; Survival; Health Care; HIV

Resumo Para analisar a relação entre utilização de cui dados de saú de e sobrevi da de pacientes com AIDS foram revisados regi stros médi cos de pacientes soroposi tivos admitidos nos servi ços de referência para AIDS em Belo Horizonte/MG, entre 1989-92. Dos 291 pacientes que evoluíram para AIDS, 57,0\% faleceram. O coefi ciente de mortal idade foi de 34,9/1.000 pessoas-mês. A mediana do tempo de sobrevida gl obal foi de 14,3 meses. A análise multivariada mostrou que indivíduos que não utilizaram AZT ( $R R=1,87$; IC 95\% =1,34-2,61), que foram classificados como estadiamento inicial "B" [sintomáticos, não AIDS] (RR =1,68; IC 95\% =1,20-2,35) e que tiveram nove ou mais dias de internação hopital ar ( $R R=1,55$; IC $95 \%=1,11-2,17$ ) apresentaram maior risco de evoluírem para óbi to. Já indivíduos que registraram pelo menos um intervalo maior de seis meses entre consultas ( $R R=0,30 ;$ IC 95\% =0,16-0,56) apresentaram menor risco de evoluirem para óbito. Os resul tados sugerem: Indi víduos com piores resultados na saúde tendem a utilizar mais os serviços e os mais complexos; Pessoas que utilizaram AZT sobreviveram mais tempo; Os marcadores de utilização adotados expressam o final de um processo de busca e obtenção da atenção.

Palavras-chave AIDS; Sobrevida; Cuidados de Saúde; HIV 


\section{Introduction}

In Brazil, the first case of Acquired Immunodeficiency Syndrome (AIDS), caused by the Human Immunodeficiency Virus (HIV), was diagnosed in 1980, and until 1987 the epidemic was restricted to the main urban centers of the Southeastern, Southern, and Central-Western regions. Since then, the epidemic has spread continuously throughout the country. Assessments of the epidemic's progression point to an increasing incidence of AIDS among patients from the lowest socioeconomic groups (Fiocruz, 1996). As of May 1997, 110,872 cases had been reported to the Ministry of Health (Brazil) with a cumulative incidence of 79.5 per 100,000 population and 54,813 (49.4\%) deaths (MS, 1997), making the epidemic one of Brazil's main public health problems. The impact on the health care system has demanded increasing efforts by the government to prevent and control the disease. However, preventive measures are still deficient in terms of both coverage and effectiveness. Despite recent developments in AIDS-related knowledge and development of new drugs and treatment, proper management of the disease is a major challenge for countries with unequal distribution of prophylactic and therapeutic resources. It is thus essential to broaden our knowledge of social and human costs of HIV infection, needs and requirements of infected patients, and barriers towards health care and consequences of delayed care. Studies on use of health care (one of the main components in evaluating access to the health care system by HIV-positive individuals) are rare in Brazil. Little information is available on either patterns in the utilization of health care by such individuals or factors that may interfere with it. Neither is it clear to what extent such barriers interfere with patient survival following AIDS diagnosis.

The present study evaluates the relationship between sociodemographic/behavioral factors, and, especially, variables related to utilization of health care and progression to death among AIDS patients using public AIDS referral services.

\section{Materials and methods}

\section{Population}

A historical cohort study was conducted in three public AIDS referral services in Belo Horizonte, Brazil: 1) an outpatient clinic for AIDS/ Sexually Transmitted Diseases (STDs), the Ores- tes Diniz Training and Reference Center (CTR) from the Belo Horizonte Municipal Health Department and the Federal University of Minas Gerais (UFMG); 2) the Eduardo de Menezes Hospital (HEM) of the Minas Gerais State Hospital Foundation; and 3) the University Hospital $(\mathrm{HCL})$ under the UFMG.

The study population consisted of all confirmed HIV-positive patients admitted to the CTR for the first time from January 1, 1989, through December 31, 1992. Patients categorized according to clinical categories proposed by the Centers for Disease Control (CDC, 1992) as " $\mathrm{A}$ " (asymptomatic, acute HIV, or persistent generalized lymphadenopathy) or "B" (symptomatic, not " $A$ " or AIDS-indicator conditions) at this first outpatient visit and who progressed to AIDS (Category "C", CDC) thereafter were assessed for survival status until December 31, 1994. Only patients admitted to the CTR were followed to check for hospitalization at HEM and $\mathrm{HCL}$.

Survival time was defined as the period between the date of AIDS diagnosis recorded on medical files and date of death as reported to the Minas Gerais State Health Authority or recorded in the medical files. Search for reported death only occurred seven months after the end of the follow-up period. This allowed sufficient time for detecting late reporting. It was thus possible to reduce the likelihood of underrecording of deaths during the study period.

A standardized form was used to collect data from clinical and laboratory records from each service. Sociodemographic and behavioral variables included age, sex, race, marital status, city of residence, education, individual monthly income, social security coverage, hemophilia, blood transfusion or hemodialysis, sexual intercourse with HIV-positive person(s), sexual intercourse with men, sexual intercourse with women, number of lifetime sexual partners, prostitution, condom use, use of any injected drug [licit or illicit], and shared needle use. All sociodemographic data were based on information collected at the first visit with the health care facilities. Continuous variables were categorized and the median was considered the cut-off point.

Variables indicative of health care utilization included the interval between the result of prior HIV test and first visit to the CTR, interval between first and second visits to the facility, interval between blood sampling for the first ELISA and communication of the result to the patient, interval between first visit to the service and first lymphocyte-T CD4+cell count, average number of outpatient visits in one year, 
number of intervals longer than six months between two outpatient visits, AZT use, number of inpatient days following AIDS diagnosis, and calendar year of first outpatient visit.

\section{Statistical analysis}

Univariate analysis was conducted to examine the association between each variable and progression to death. The Kaplan-M eier method (Kahn \& Sempos, 1989) was used to estimate the cumulative probability of patient survival time. Comparison of different curves according to subgroups was conducted using the logrank test. Significance level adopted was 0.05 . Relative hazards of death after AIDS, with $95 \%$ confidence interval, was assessed through Cox Proportional Hazards model (Cox \& Oakes, 1984) for both univariate and multivariate estimates.

The independent effect of selected variables on progression to death was assessed in the multivariate analysis. Variables statistically associated $(p<0.10)$ with progression to death in the univariate analysis as well as those considered clinically and epidemiologically relevant were fitted. Modeling began with all variables followed by sequential deletion according to their statistical importance. Each variable was assessed and models were compared using the likelihood ratio test (SERC, 1993).

\section{Results}

\section{Descriptive statistics}

The study included 291 HIV-positive subjects registered at the CTR between January 1,1989 , and December 31, 1992, who progressed to AIDS by December 31, 1994. Most patients were referred to the CTR for the first time by physicians (63.6\%) and reasons included: confirmation of HIV diagnosis (42.3\%), follow-up/ treatment of AIDS (23.7\%), initial HIV testing (22.3\%), and unknown (11.7\%). During the follow-up period, 228 (78.3\%) patients were referred for admission to the two hospitals and $220(75.6 \%)$ were actually admitted at least once. HEM was the first hospital of admission for 141 (64.1\%) and HCL for 37 (16.8\%) patients. Sociodemographic and behavioral characteristics/ source of infection of the patients are shown in Table 1. Most patients were aged 30 or over, single, male, white, had 8+years of schooling, resided in Belo Horizonte, had incomes under three times the minimum wage [i.e., less than approximately $U \$ 325 /$ month -
Table 1

Sociodemographic and behavioral characteristics/source of infection among patients admitted to $O$ restes Diniz Training and Reference Center who developed AIDS, Belo Horizonte, Brazil, 1989-1994.

\begin{tabular}{|c|c|c|}
\hline Characteristic & $\mathrm{n} *$ & $\%$ \\
\hline \multicolumn{3}{|l|}{ Sociodemographic } \\
\hline Age ( $\geq 30$ years) & 178 & 61.2 \\
\hline Single & 213 & 73.4 \\
\hline Male & 245 & 84.2 \\
\hline White & 167 & 59.2 \\
\hline Schooling (8+ years) & 167 & 58.8 \\
\hline Resident in Belo-Horizonte & 192 & 66.0 \\
\hline Monthly income (<3 minimum wages) & 147 & 54.6 \\
\hline Social security coverage & 220 & 86.6 \\
\hline \multicolumn{3}{|l|}{ Behavior/source of infection } \\
\hline Hemophilia & 7 & 2.5 \\
\hline Blood transfusion/ hemodialysis & 33 & 11.8 \\
\hline Use of some injected drug & 160 & 60.8 \\
\hline Shared needles & 29 & 10.6 \\
\hline Sexual partners $(>100)$ & 59 & 24.8 \\
\hline Sexual intercourse with HIV-positive person(s) & 57 & 32.6 \\
\hline History of prostitution & 18 & 7.4 \\
\hline History of sexually transmitted disease & 227 & 79.4 \\
\hline Condom use $\geq 50 \%$ in sexual intercourse & 36 & 15.1 \\
\hline Sexual intercourse with men only & 59 & 21.3 \\
\hline Sexual intercourse with men and women & 119 & 43.0 \\
\hline Sexual intercourse with women only & 48 & 17.3 \\
\hline Heterosexual women & 40 & 14.4 \\
\hline Sexual practice ignored or abstinent & 25 & 8.6 \\
\hline
\end{tabular}

* Missing values were excluded.

Translator's note], and had social security coverage. Only $15.1 \%$ reported at least $50 \%$ condom use during sexual intercourse, $79.4 \%$ had a history of STDs, $60.8 \%$ had used licit or illicit injectable drugs, $32.6 \%$ reported sexual intercourse with HIV-positive person(s), and $24.8 \%$ had $100+$ lifetime sexual partners.

Results of variables indicating utilization of health care showed that: 1) mean number of outpatient visits per year following diagnosis of AIDS was 26.9 (median $=17.1$ ); 2) AZT use was recorded in 149 (51.4\%) of the patient files; 3 ) mean number of inpatient days following AIDS diagnosis was 20.1 (median =8.0); 4) mean interval between first and second outpatient visit was 50.1 days (median $=20.0$ ); 5 ) mean interval between blood sample and communicating the first ELISA result was 50.4 days (median $=23.0$ ); 6) mean interval between an HIV test result prior to admission to the health care facility and first outpatient visit was 150.6 days (median =47.0); and $\mathrm{h}$ ) mean interval between first 
outpatient visit and first lymphocyte-T CD4+ cell count was 317.8 days (median $=176.0$ ).

Univariate analysis

Of the 291 patients progressing to AIDS during the observation period, 166 (57.0\%) died (mortality rate $=34.9 \%$ person-months). None of the sociodemographic or risk behavior characteristics assessed was statistically associated with progression to death among the patients developing AIDS during the period (Table 2). However, proportion of death was higher among women (67.4\%) and those with less than eight years of schooling (61.5\%), income less than three times the minimum wage $(60.5 \%)$, no social security coverage (61.8\%), illicit injectable drug use (IDU) (69.0\%), and previous history of STDs (60.8\%).

Table 3 shows univariate analysis of characteristics related to the utilization of health care and progression to death. Patients who did not use AZT were at increased risk of dying as compared to those who taking the drug $(\mathrm{RR}=1.67$; $95 \% \mathrm{Cl}=1.22-2.26$ ). Highest proportion of death was observed in patients hospitalized for nine days or longer $(\mathrm{RR}=1.46 ; 95 \% \mathrm{Cl}=1.07-2.00$ ). Remaining variables showed a trend towards a protective effect $(R R<1)$. However, only occurrence of intervals greater than six months between two outpatient visits was statistically significant ( $\mathrm{RR}=0.50 ; 95 \% \mathrm{Cl}=0.31-0.80)$. In addition, patients registered with the facility in 1991, who were classified as category " $B$ " at initial staging and whose first lymphocyte-T CD4+cell count was below $0.20 \times 109 / \mathrm{L}\left(200 / \mathrm{mm}^{3}\right)$ presented higher risk of progression to death $(p \leq 0.05)$.

\section{Survival time}

Median survival time following AIDS diagnosis was 14.3 months (17.8 months for initial CDC category " $\mathrm{A}$ " and 10.4 months for initial CDC category " $B$ "). No sociodemographic or risk behavior variable showed significant difference in median survival time. With regard to characteristics in utilization of health care, median survival time was significantly higher compared to the respective reference subgroups among patients who used AZT (Yes $=19.7$ months, No $=5.8$ months; $p=0.001$ ), were hospitalized for less than nine days $(<\theta=21.7$ months, $9+=9.7$ months; $p=0.016$ ), and had intervals between two outpatient visits greater than six months (Yes $=40.4$ months, No $=10.6$ months; $p=0.002$ ) (Kaplan-Meier curves are shown for AZT use and number of inpatient days in Figures 1 and 2, respectively).

\section{Multivariate analysis}

Based on the univariate analysis and on clinical and epidemiological considerations, the following variables were chosen to start a complete model: intervals greater than six months between outpatient visits, AZT use, initial staging, number of inpatient days, interval between first and second outpatient visits, age at admission, race, and gender. Although baseline lymphocyte-T CD4+cell count was associated with increased risk in the univariate analysis, it was excluded from multivariate analysis due to the high number of missing values. This does not necessarily reflect loss of or incomplete data, but rather unavailability of such an important test during the study period.

The final model indicated that lack of AZT use $(\mathrm{RR}=1.87 ; 95 \% \mathrm{Cl}=1.34-2.61)$, admission to the facility with more advanced staging (category “B”) ( $R R=1.68 ; 95 \% \mathrm{Cl}=1.20-2.35)$, and hospitalization for nine days or more (RR = 1.55; $95 \% \mathrm{Cl}=1.11-2.17$ ) were associated with death in this population, while an interval between two outpatient visits greater than six months showed a protective effect ( $R R=0.30$; $95 \% \mathrm{Cl}=0.16-0.56$ ) (Table 4). The proportional hazards assumption was tested using Schoenfeld residuals (Venables \& Ripley, 1994) and found to be valid for the variables modeled, except for AZT use. Nevertheless, AZT use was kept in the final model because it explains most of the data's variability, generating more precise and unaltered point estimates for the remaining variables.

\section{Discussion}

Cumulative proportion of death in this prevalent cohort presents an intermediate value (55.9\%) as compared to other studies conducted in different time periods and countries and with different observation periods (Henriques et al., 1992; Jacobson et al., 1993; Chaisson et al., 1995; Volberding et al., 1995; Brettle et al., 1996). Median survival time following AIDS diagnosis was 14.3 months, longer than that verified in a previous study conducted in Brazil [5.1 months] (Castilho et al., 1992) and closer to that observed in developed countries [range from 10.3 to 21.4 months] (Guimarães, 1992). When stratifying by initial staging, patients classified as category " $\mathrm{A}$ " presented median survival time 1.7 times that of patients in category " $B$ ". No difference in median survival time was found for sociodemographic or risk behavior characteristics for the overall study popula- 
Table 2

Univariate analysis of progression to death among patients admitted to O restes Diniz Training and Reference Center, according to sociodemographic and behavioral characteristics/source of infection, Belo Horizonte, Brazil, 1989-1994.

\begin{tabular}{|c|c|c|c|c|}
\hline Characteristic & $\begin{array}{c}\text { Total } \\
\text { n* }\end{array}$ & $\begin{array}{l}\text { Death** } \\
\mathrm{n}(\%)\end{array}$ & $\begin{array}{l}\text { Relative Risk*** } \\
\quad(95 \% \mathrm{Cl})\end{array}$ & $p$ value \\
\hline \multicolumn{5}{|l|}{ 1) Age } \\
\hline 30 years + & 178 & $100(56.2)$ & $1.05(0.77-1.43)$ & 0.76 \\
\hline$<30$ years & 113 & $66(58.4)$ & 1.0 & \\
\hline \multicolumn{5}{|l|}{ 2) Sex } \\
\hline Female & 46 & $31(67.4)$ & $1.35(0.91-1.99)$ & 0.14 \\
\hline Male & 245 & $135(55.1)$ & 1.0 & \\
\hline \multicolumn{5}{|l|}{ 3) Race } \\
\hline Non-white & 115 & $65(56.5)$ & $0.89(0.65-1.21)$ & 0.45 \\
\hline White & 167 & $97(58.1)$ & 1.0 & \\
\hline \multicolumn{5}{|l|}{ 4) Marital status } \\
\hline Unstable & 237 & $135(57.0)$ & $0.92(0.62-1.36)$ & 0.67 \\
\hline Stable & 53 & $31(58.5)$ & 1.0 & \\
\hline \multicolumn{5}{|l|}{ 5) Residence } \\
\hline O ther cities & 99 & $52(52.5)$ & $0.92(0.66-1.28)$ & 0.61 \\
\hline Belo Horizonte & 192 & $113(58.9)$ & 1.0 & \\
\hline \multicolumn{5}{|l|}{ 6) Schooling } \\
\hline$<8$ years & 117 & $72(61.5)$ & $1.24(0.91-1.69)$ & 0.17 \\
\hline 8 years + & 167 & $91(54.5)$ & 1.0 & \\
\hline \multicolumn{5}{|l|}{ 7) Individual monthly income } \\
\hline$<3$ times minimum wage & 147 & $89(60.5)$ & $1.07(0.78-1.47)$ & 0.66 \\
\hline 3 times minimum wage + & 122 & $68(55.7)$ & 1.0 & \\
\hline \multicolumn{5}{|l|}{ 8) Social security } \\
\hline No & 34 & $21(61.8)$ & $1.07(0.67-1.70)$ & 0.78 \\
\hline Yes & 220 & $123(55.9)$ & 1.0 & \\
\hline \multicolumn{5}{|l|}{ 9) Lifetime sexual partners } \\
\hline $100+$ & 59 & $33(55.9)$ & $0.99(0.67-1.46)$ & 0.95 \\
\hline$<100$ & 179 & $107(59.8)$ & 1.0 & \\
\hline \multicolumn{5}{|c|}{ 10) Behavior/source of infection } \\
\hline Hemophilia/Transfusion & 33 & $21(63.6)$ & $0.95(0.55-1.66)$ & 0.86 \\
\hline Injecting Drug User & 29 & $20(69.0)$ & $1.23(0.76-2.00)$ & 0.40 \\
\hline Sexual & 225 & $125(55.6)$ & 1.0 & \\
\hline \multicolumn{5}{|l|}{ 11) History of STDs } \\
\hline Yes & 227 & $138(60.8)$ & $1.27(0.84-1.92)$ & 0.26 \\
\hline No & 59 & $27(45.8)$ & 1.0 & \\
\hline
\end{tabular}

* Total for each variable differs due to missing values.

** N umber and proportion of individuals who died in the period.

*** Relative risks (hazards) were obtained using Cox proportional hazards model. 
Table 3

Univariate analysis of progression to death among patients admitted to Orestes Diniz Training and Reference Center, according to characteristics related to utilization of health care, Belo-Horizonte, Brazil, 1989-1994.

\begin{tabular}{|c|c|c|c|c|}
\hline Characteristic & $\begin{array}{c}\text { Total } \\
\mathrm{n}^{1}\end{array}$ & $\begin{array}{c}\text { Death2 } \\
n(\%)\end{array}$ & $\begin{array}{l}\text { Relative Risk } 3 \\
\quad(95 \% \mathrm{Cl})\end{array}$ & $\mathrm{p}$ value \\
\hline \multicolumn{5}{|c|}{ 1) O utpatient visits/year 4} \\
\hline$<17$ & 202 & $110(54.5)$ & $0.81(0.58-1.12)$ & 0.20 \\
\hline $17+$ & 89 & $56(62.9)$ & 1.0 & \\
\hline \multicolumn{5}{|c|}{ 2) Intervals > 6 months 5} \\
\hline Yes & 46 & $20(43.5)$ & $0.50(0.31-0.80)^{*}$ & $<0.01$ \\
\hline No & 245 & $146(59.6)$ & 1.0 & \\
\hline \multicolumn{5}{|l|}{ 3) AZT use } \\
\hline No & 141 & $89(63.1)$ & $1.67(1.22-2.26)^{*}$ & $<0.01$ \\
\hline Yes & 149 & $77(51.7)$ & 1.0 & \\
\hline $9+$ & 144 & $94(65.3)$ & $1.46(1.07-2.00)^{*}$ & 0.02 \\
\hline$<9$ & 139 & $69(49.6)$ & 1.0 & \\
\hline \multicolumn{5}{|c|}{ 5) 1st $O$ utpatient visit/2nd O utpatient visit6 } \\
\hline 21 days + & 145 & $73(50.3)$ & $0.74(0.54-1.02)$ & 0.07 \\
\hline$<21$ days & 123 & $78(63.4)$ & 1.0 & \\
\hline \multicolumn{5}{|c|}{ 6) Blood sample taken/Communication ELISA6 } \\
\hline 24 days + & 67 & $33(49.3)$ & $0.82(0.52-1.28)$ & 0.38 \\
\hline$<24$ days & 75 & $45(60.0)$ & 1.0 & \\
\hline \multicolumn{5}{|c|}{ 7) Prior HIV test/ 1 st 0 utpatient visit6 } \\
\hline 48 days + & 74 & $39(52.7)$ & $0.95(0.61-1.48)$ & 0.81 \\
\hline$<48$ days & 64 & $39(60.9)$ & 1.0 & \\
\hline 177 days + & 34 & $12(35.3)$ & $0.72(0.38-1.35)$ & 0.31 \\
\hline$<177$ days & 102 & $51(50.0)$ & 1.0 & \\
\hline \multicolumn{5}{|c|}{ 9) Year registered with the service } \\
\hline 1989 & 53 & $36(67.9)$ & $1.44(0.93-2.22)$ & 0.10 \\
\hline 1990 & 85 & $48(56.5)$ & $1.20(0.78-1.83)$ & 0.41 \\
\hline 1991 & 70 & $43(61.4)$ & $1.75(1.11-2.76)^{*}$ & 0.02 \\
\hline 1992 & 83 & $39(47.0)$ & 1.0 & \\
\hline \multicolumn{5}{|c|}{ 10) Initial staging 7} \\
\hline Category "B" & 147 & $98(66.7)$ & $1.46(1.07-1.99)^{*}$ & 0.02 \\
\hline Category " $A$ " & 144 & $68(47.2)$ & 1.0 & \\
\hline \multicolumn{5}{|c|}{ 11) 1st lymphocyte-T CD4+count } \\
\hline$<0.20 \times 109 / \mathrm{L}$ & 64 & $36(56.3)$ & $1.63(1.00-2.67)^{*}$ & 0.05 \\
\hline $0.20 \times 109 / \mathrm{L}+$ & 76 & $29(38.2)$ & 1.0 & \\
\hline
\end{tabular}

1 Total for each variable differs due to missing values.

2 Number and proportion of individuals who died in the period.

3 Relative risks (hazards) were obtained using Cox proportional hazards model.

4 Average number of outpatient visits per year.

5 Intervals longer than six months between two outpatient visits.

6 Intervals between two events.

7 According to CDC Classification System , 1993; Category "A" = asymptomatic, acute HIV or PGL,

Category " $B$ " = symptomatic, not " $A$ " or " $C$ " conditions; Category " $C$ " = AIDS-indicator conditions.

* Statistically significant. 


\section{Figure 1}

Kaplan-M eier analysis of survival after AIDS diagnosis, according to AZT use.

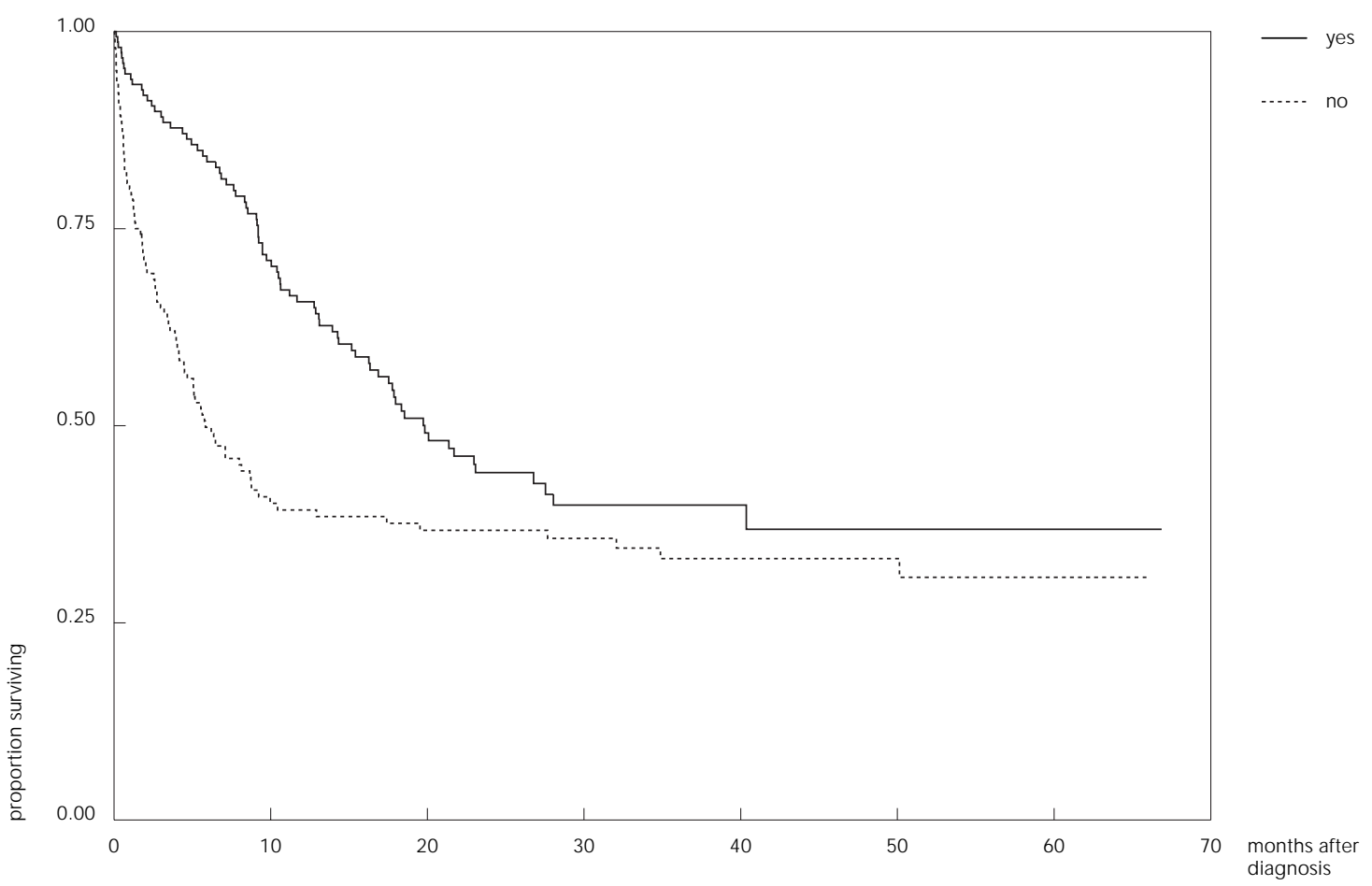

Figure 2

Kaplan-M eier analysis of survival after AIDS diagnosis according to number of days hospitalized.

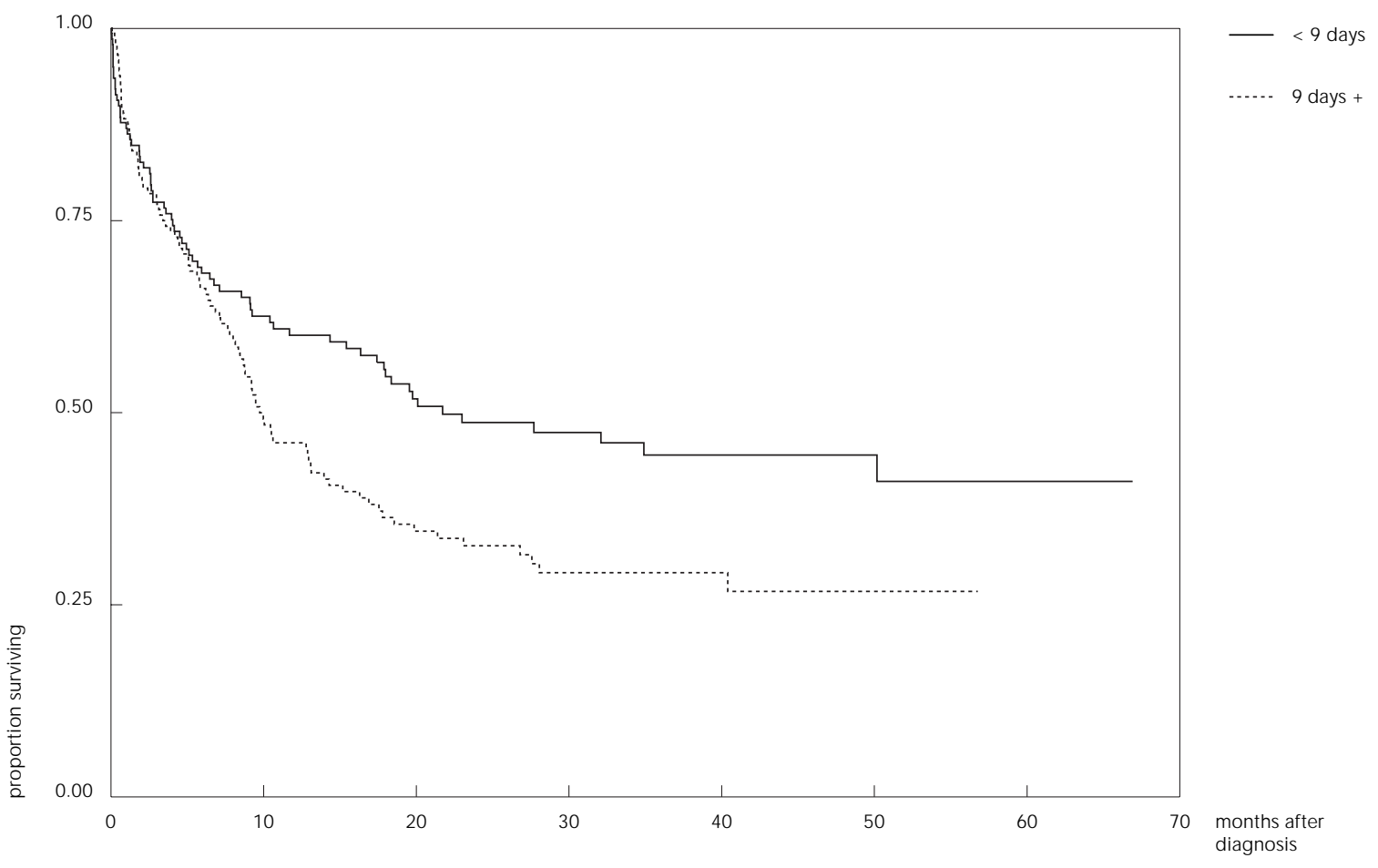


Table 4

Final model of the multivariate analysis among patients admitted to O restes Diniz Training and Reference Center, with relative hazards of death following AIDS diagnosis, Belo Horizonte, Brazil, 1989-1994.

\begin{tabular}{ll}
\hline Characteristic & RR $(95 \% \mathrm{CI})$ \\
\hline Intervals > 6 months' (Yes) & $0.30(0.16-0.56)$ \\
AZT use (No) & $1.87(1.34-2.61)$ \\
Initial staging2 (Category “ $\left.\mathrm{B}^{\prime}\right)$ & $1.68(1.20-2.35)$ \\
Inpatient days3 $(9+)$ & $1.55(1.11-2.17)$
\end{tabular}

1 Intervals longer than six months between two outpatient visits.

2 According to CDC Classification System, 1993; Category" $A^{\prime \prime}=$ asymptomatic, acute HIV or PGL, Category " $B$ " = symptomatic, not" $A$ " or " $C$ " conditions;

Category "C" = AIDS-indicator conditions.

3 Days hospitalized following AIDS diagnosis.

tion. Consistently, no sociodemographic variable included in the multivariate analysis presented an independent effect on survival time. Other studies have shown similar results (Jacobson et al., 1993; Chaisson et al., 1995) and suggested that associations between these characteristics and mortality may reflect differences in health care utilization.

Median survival was significantly greater among patients who used AZT, while patients not using AZT presented an increased risk of dying ( $R R=1.87 ; 95 \% \mathrm{Cl}=1.34-2.61$ ). It is worth mentioning that AZT use was rare at the beginning of the study period: only four people among the study population reported AZT use before 1990, and three had symptoms. These data demonstrate consistency with distribution of AZT by the public sector during this period in Brazil, when the drug was provided only to individuals with more severe symptoms. In Brazil, a more regular supply of the drug by public health services has only occurred recently. Several studies have reported benefit of AZT use on progression to death, especially among patients in more advanced stages of HIV infection (Fischl et al., 1987; Hidalgo et al., 1990; Hamilton et al., 1992; Turner et al., 1994; Chaisson et al., 1995; Brettle et al., 1996; Simberkoff et al., 1996). However the survival advantage conferred by zidovudine may be constrained by time (GASG, 1994; CCC, 1994; Volberding et al., 1995; Simberkoff et al., 1996; Moore et al., 1996). AZT monotherapy is not currently recommended (Jabionowski, 1995; Hammer et al., 1996; DCC, 1996) due to significant developments in the knowledge and availability of new drugs. Combination therapies have provided better life expectancy for patients with HIV infection, but long-term prognosis is not clear (Enger et al., 1996). Further- more, cost of recently available drugs is an important barrier to accessing treatment.

Patients who were exposed to longer intervals between two events (e.g., first and second outpatient visit) showed longer survival. Other markers of health care utilization demonstrated similar trends: better results in survival were observed among patients who had lower average number of outpatient visits per year and lower number of inpatient days and recorded at least one interval between two outpatient visits greater than six months. In the multivariate analysis, increased survival was associated with the last two variables. It should be noted that the study was limited to patients admitted to the three public services and was only based on information from patient files, which in most cases did not explicitly state the possible simultaneous use of other services by the patient. Although this could have affected our estimates, we consider it a remote possibility given that: a) during the study period these were the only public AIDS referral services available in Belo Horizonte; b) income level of participants was incompatible with frequent use of private services; and c) other hospitals rarely admitted HIV-infected patients at the time of the study.

The literature indicates the level and pattern of the population's actual utilization of the system as a measurement that may be used to test the predictive validity of access indicators (Aday \& Andersen, 1974). In fact, utilization of health care services, one of the components of access, expresses the end of a process involving seeking and obtaining care. This should be taken into account when assessing impact of care on survival among HIV-infected patients.

The study demonstrated that patients with worse results in survival tended to use the services more often and to use more complex services. This finding is consistent with results of other studies (Mor et al., 1992; Solomon et al., 1992; Hellinger et al., 1994a., 1994b; Turner et al., 1994; Zucconi et al., 1994; Carlin et al., 1996; Horner et al., 1996) reporting the same variation in health care utilization due to greater severity of disease or worse results in health. A possible explanation for the observed association may be that access is an adjustment factor between health service characteristics and population characteristics. Such adjustment expresses a relationship between a set of obstacles in seeking and obtaining care (resistance) on the one hand, and the ability of the population to overcome these obstacles (utilization power) on the other hand (Frenk, 1985). Accordingly, patients who perceive greater severi- 
ty in the progression of their disease and those who have symptoms may present greater utilization power, to the extent that they are more motivated to obtain care from services and therefore display greater tolerance towards obstacles (e.g. waiting time to obtain care, shifts). Organization of services may also be more "permeable" to access by more severe patients, creating mechanisms that make admission easier, even in situations of limited availability of resources.

These findings foster a better understanding of the dynamics involving health care sup-

\section{Acknowledgments}

The research was supported by a grant (HDP/HDR/ HPC-HCA/RG/BRA ID.1013) from the Pan-American Health Organization. The authors wish to thank the staff of the following institutions: Orestes Diniz Training and Reference Center, Eduardo de Menezes Hospital, University Hospital of the Federal University of Minas Gerais, Belo Horizonte Municipal Health Department, and Minas Gerais State Hospital Foundation for their continued support of this work. We would also like to thank Suzana Faria Gontijo Assunção. ply and utilization of services by HIV-infected patients and may be useful in planning and organizing services. Since access to medical care has been identified as an important predictor of survival (Chaisson et al., 1995), it is essential to tackle the challenge of increasing its availability, equity, and quality, providing early intervention with emphasis on outpatient care, and assuring continuity. Further studies, using primary data sources and qualitative assessment methods, should be conducted to further explore the process of seeking and obtaining health care.

\section{References}

ADAY, L. A. \& ANDERSEN, R., 1974. A framework for the study of access to medical care. Health Services Research, 9:208-220.

BRETTLE, R. P.; MCNEIL, A. J.; BURNS, S.; GORE, S. M.; BIRD, A. G.; YAP, P. L.; MaCCALLUM, L.; LEEN, C. S. L. \& RICHARDSON, A. L., 1996. Progression of HIV: follow-up of Edinburgh injecting drug users with narrow seroconversion intervals in 1983-1985. AIDS, 10:419-430.

CARLIN, J. B.; LANGDON, P. \& HURLEY, S. F., 1996. Health care and its costs for children with perinatally acquired HIV infection. Journal of Paediatrics and Child Health, 32:42-47.

CASTILHO, E. A.; CHEQUER, P. \& STRUCHINER, C. J., 1992. AIDS no Brasil. Informe Epidemiológico do SUS, 1:115-124.

CCC (Concorde Coordinating Committee), 1994. Concorde: MCR/ANRS randomised double-blind controlled trial of immediate and deferred zidovudine in sympton-free HIV infection. Lancet, 343: 871-881.

CDC (Centers for Disease Control and Prevention), 1992. 1993 Revised classification system for HIV infection and expanded surveillance case definition for AIDS among adolescents and adults. Morbidity and Mortality Weekly Report, 41:1-4.

CHAISSON, R. E.; KERULY, J. C. \& MOORE, R. D., 1995. Race, sex, drug use, and progression of human immunodeficiency virus disease. New England Journal of Medicine, 333:751-756.

COX, D. R. \& OAKES, D., 1984. Analysis of Survival Data. New York: Chapman and Hall.

DCC (Delta Coordinating Committee), 1996. Delta: a randomized double-blind controlled trial comparing combinations of zidovudine plus didanosine or zalcitabine with zidovudine alone in HIVinfected individuals. Lancet, 348:283-291.

ENGER, C.; GRAHAM, N.; PENG, Y.; CHMIEL, J. \& KINGSLEY, L., 1996. Survival from early, intermediate and late stages of HIV infection. Journal of American Medical Association, 275:1329-1334.

FIOCRUZ (Fundação Oswaldo Cruz), 1996. AIDS no Brasil: uma epidemia em mutação. Dados, 18:7-12.

FISCHL, M. A.; RICHMANN, D. D.; GRIECO, M. H.; LASKIN, O. L.; LEEDOM, J. M.; GROOPMAN, J. F.; 
MILDVAN, D.; SCHOOLEY, R. T.; JACKSON, G. G.; DURACK, D. T. \& KING, D., 1987. The efficacy of azidothymidine (AZT) in the treatment of patients with AIDS and AIDS-related complex: a double-blind controlled trial. New England Journal of Medicine, 317:185-191.

FRENK, J., 1985. El concepto y la medicion de accesibilidad. Salud Pública de Mexico, 27:438-453.

GASG (German AIDS Study Group), 1994. Survival of patients receiving zidovudine before or after AIDS diagnosis: results of a German multicenter study. Clinical Investigator, 72:111-116.

GUIMARÃES, M. D. C., 1992. Heterosexual transmission of the human immunodeficiency virus in Brazil: a comparison of sexual practices. Doctor of Science dissertation, Baltimore: Johns Hopkins University.

HAMILTON, J. D.; HARTIGAN, P. M.; SIMBERKOFF, M. S.; DAY, P. L.; DIAM OND, G. R.; DICKINSON, G. M.; DRUSANO, G. L.; EGORIN, M. J.; GEORGE, W. L.; GORDIN, F. M.; HAWKES, C. A.; JENSEN, P. C.; KLIMAS, N. G.; LABRIOLA, A. M.; LAHART, C. J.; O'BRIEN, W. A.; OSTER, C. N.; WEINHOLD, K. J.; WRAY, N. P. \& ZOLLA-PAZNER, S. B., 1992. A controlled trial of early versus late treatment of zidovudine in symptomatic human immunodeficiency virus infection: results of the Veterans Affairs Cooperative Study. New England Journal of Medicine, 326:437-443.

HAMMER, S. M.; KATZENSTEIN, D. A.; HUGHES, M. D.; GUNDACKER, H.; SCHOOLEY, R. T.; HAUBRICH, R. H.; HENRY, W. K.; LEDERMAN, M. M.; PHAIR, J. P.; NIU, M.; HIRSCH, M. S. \& MERIGAN, T. C., 1996. A trial comparing nucleoside monotherapy with combination therapy in HIVinfected adults with CD 4 cell counts from 200 to 500 per cubic millimeter. New England Journal of Medicine, 335:1081-1090.

HELLINGER, F. J.; FLEISHMAN, J. A. \& HSIA, D. C., 1994a. Correlates of medical service utilization among people with HIV infection. Health Services Research, 29:527-548.

HELLINGER, F. J.; FLEISHMAN, J. A. \& HSIA, D. C., 1994b. AIDS treatment costs during the last months of life: evidence from the ACSUS. Health Services Research, 29:569-581.

HENRIQUES, C. M. P.; BORGES FILHO, T. S. \& RODRIGUES, C. O., 1992. Curvas de sobrevivência de pacientes de AIDS em Santos, Brasil. Revista de SaúdePública, 26:295-298.

HIDALGO, J.; SUGLAND, B.; MOORE, R. \& CHAISSON, R. E., 1990. Access, equity, and survival: use of ZVD and pentamidine by persons with AIDS. VI International Conference on AIDS, pp. 148, San Francisco.

HORNER, R. D.; BENNETT, C. L.; ACHENBACH, C.; RODRIGUEZ, D.; ADAMS, J.; GILMAN, S. C.; COHN, S. E.; DICKINSON, G. M.; DEHOVITZ, J. A. \&WEINSTEIN, R. A., 1996. Predictors of resource utilization for hospitalized patients with Pneumocystis carinii pneumonia (PCP): a summary of effects from the multi-city study of quality of PCP care. Journal of Acquired Immune Deficiency Syndromes and Human Retrovirology, 12:379-385.

JABIONOWSKI, H., 1995. Studies of zidovudine in combination with didanosine and zalcitabine.
Journal of Acquired Immune Deficiency Syndromes and Human Retrovirology, 10(Sup. 1): S52-S56.

JACOBSON, L. P.; KIRBY, A. J.; POLK, S.; PHAIR, J. P.; BESLEY, D. R.; SAAH, A. J.; KINGSLEY, L. A. \& SCHRAGER, L. K., 1993. Changes in survival after acquired immunodeficiency syndrome (AIDS): 1984-1991. American Journal of Epidemiology, 136:952-964.

KAHN, H. A. \& SEM POS, C. T., 1989. Statistical Methods in Epidemiology. Second edition. New York: Oxford University Press.

MS (Ministério da Saúde), Coordenação Nacional de Doenças Sexualmente Transmissíveis e AIDS, 1997. AIDS Boletim Epidemiológico, 6:8-24.

MOORE, R. D.; KERULY, J. C. \& CHAISSON, R. E., 1996. Duration of the survival benefit of zidovudine therapy in HIV infection. Archives of Internal Medicine, 156: 1073-1077.

MOR, V.; FLEISHMAN, J. A.; DRESSER, M. \& PIETTE, M. S., 1992. Variation in health service use among HIV-infected patients. Medical Care, 30:17-29.

SERC (Statistics and Epidemiology Research Corporation), 1993. EGRET. Seattle: SERC.

SIMBERKOFF, M. S.; HARTIGAN, P. M.; HAMILTON, J. D.; DAY, P. L.; DIAMOND, G. R.; DICKINSON, G. M.; DRUSANO, G. L.; EGORIN, M. J.; GEORGE, W. L.; GORDIN, F. M.; HAWKES, C.A.; JENSEN, P.C.; KLIMAS, N. G.; LABRIOLA, A.M.; LAHART, C. J.; O'BRIEN, W. A.; OSTER, C. N.; WEINHOLD, K. J.; WRAY, N. P. \& ZOLLA-PAZNER, S. B., 1996. Longterm follow-up of symptomatic HIV-infected patients originally randomized to early versus later zidovudine treatment: report of a Veterans Affairs cooperative study. Journal of Acquired Immune Deficiency Syndromes and Human Retrovirology, 11:142-150.

SOLOMON, L.; FRANK, R.; VLAHOV, D. \& ASTEMBORSKI, J., 1992. Utilization of health services in a cohort of intravenous drug users with known HIV1 serostatus. American Journal of Public Health, 81:1285-1290.

TURNER, B. J.; MARKSON, L. E.; MCKEE, L. J.; HOUCHENS, R. \& FANNING, T., 1994. Health care delivery, zidovudine use, and survival of women and men with AIDS. Journal of Acquired Immune Deficiency Syndromes, 7:1250-1262.

VENABLES, W. U. \& RIPLEY, B. D. Survival Analysis. In: Modern Applied Statistics with S-Plus (W. U. Venables \& B. D. Ripley, eds.), pp. 267-300, New York: Springer.

VOLBERDING, P. A.; LAGAKOS, S. W.; GRIMES, J. M.; STEIN, D. S.; ROONEY, J.; MENG, T.; FISCHL, M. A.; COLLIER, A. C.; PHAIR, J. P.; HIRSCH, M. S.; HARDY, W. D.; BALFOUR, H. H. \& REICHMAN, R. C., 1995. A comparison of immediate with deferred zidovudine therapy for asymptomatic HIVinfected adults with CD4 cell counts of 500 or more per cubic millimeter. The New England Journal of Medicine, 333:401-407.

ZUCCONI, S. L.; JACOBSON, L. P.; SCHRAGER, L. K.; KASS, N. E.; LAVE, J. R.; CARSON, C. A.; MORGENSTERN, H.; ARNO, P. S. \& GRAHAM, N. M. H.,1994. Impact of immunosuppression on health care use by men in the Multicenter AIDS Cohort Study. Journal of Acquired Immune Deficiency Syndromes, 7:607-616. 